Volume 8. No. 9, September 2020

International Journal of Emerging Trends in Engineering Research

Available Online at http://www.warse.org/IJETER/static/pdf/file/ijeter94892020.pdf

https://doi.org/10.30534/ijeter/2020/94892020

\title{
Sustainable Efficiency of Hypo Sludge in Concrete
}

\author{
D.S.Vijayan ${ }^{1}$, A. Leema Rose ${ }^{2}$, P.Dinesh Kumar ${ }^{3}$, V.Gokulnath ${ }^{4}$, D Parthiban ${ }^{5}$ \\ ${ }^{1}$ Civil Engineering Department, Aarupadai Veedu Institute of Technology, VMRF, TN, India. vijayan @ avit.ac.in \\ ${ }^{2}$ Civil Engineering Department, SRM Valliammai Engineering College, Chennai, India. \\ leema_arose@yahoo.com \\ ${ }^{3}$ Civil Engineering Department, Krishnasamy college of engineering and Technology, India. \\ dinesh.structures@gmail.com \\ ${ }^{4}$ Saveetha School of Engineering, Saveetha Institute of Medical \& Technical Sciences, TN, India. \\ gokulnath4civil@gmail.com \\ Civil Engineering Department, Aarupadai Veedu Institute of Technology, VMRF, TN, India. \\ parthiban.civil@avit.ac.in
}

\begin{abstract}
The paper producing industry generates various wastes which are said to be hypo-sludge. Cement with Hypo sludge reduces the permeability of concrete and dense calcium silicate hydrate. The mix designed for M20 and M40 grade of concrete. The Research is concerned with Environmental-friendly Usage of hypo sludge as replacement to cement for 10, 20 and $30 \%$. The compressive strength and flexural strength is found for 7 and 28 days. The strength achieved for compressive strength is increased till $20 \%$. The young's modulus is found for 10 and $20 \%$. The strength achieve for young's modulus is increased till $10 \%$ for both the grade. The project is based on sustainable development of concrete technology with eco-friendly environment.
\end{abstract}

Key words : Cementitious material, Compressive strength, Eco-friendly environment, Flexural strength, Permeability.

\section{INTRODUCTION}

More than 300 million tons of mechanical waste are being delivered per annum by concoction and farming procedure in India [1]. These materials present issues to wellbeing risks. Paper making by and large creates enormous measure of strong waste. Paper filaments can be reused just a predetermined number of times before they become excessively short or powerless to make top notch paper. The sparkling completion on lustrous magazine created utilizing a fine kaolin dirt covering, which additionally gets strong waste during reusing [7]. The strong squanders for paper industry are utilized in creating stream and vitality in power station. The expected outcome of the hypo Sludge which is extracted from the factory is shown in the figure 1.

Use either SI (MKS) or CGS as primary units. (SI units are

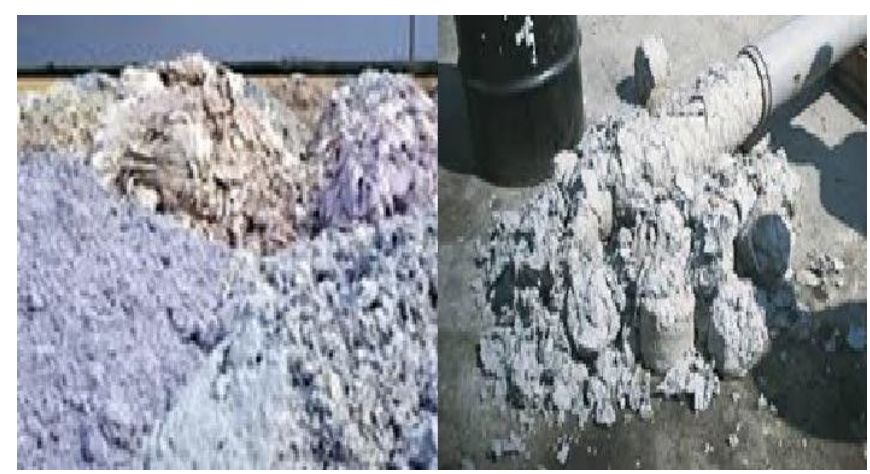

Figure 1: Hypo Sludge Production from Factory

To deliver 1 tons of Portland Pozzolanic Cement tremendous measure of carbon-di-oxide is discharged into air which is unsafe to human wellbeing. Almost $10 \%$ to $30 \%$ of hypo muck can be utilized rather than concrete in solid street development [4]. The sparkling completion on lustrous magazine delivered utilizing a fine kaolin mud covering. Which additionally gets strong waste during reusing. The strong waste for paper industry are utilized in delivering stream and vitality in power station. To create 1 tons of Portland Pozzolanic Cement enormous measure of carbon-di-oxide is discharged into environment which is dangerous to human health. Nearly $10 \%$ to $30 \%$ of hypo slop can be utilized rather than concrete in solid street development

\section{EXPERIMENTAL PROGRAM}

\subsection{Cement}

The Cement makes concrete more impermeable, denser as compared to make the concrete[5]. Cement is the most valuable material to prepare the concrete which is used for the binding property of the materials used in the concrete. In this research we have used ordinary Portland cement which is not contain any fly Ash in the cement. 


\subsection{Fine Aggregate}

The sizes from $4.75 \mathrm{~mm}$ to 75 micron are selected as fine aggregate. Basically river sand which is used as a fine aggregate commonly extracted from the river bed and It has to satisfied the codel provision requirements of IS: 383-1970 [15]. The river fine aggregate is screened, to eliminate over size particles. The fine aggregate taken is passed through $4.75 \mathrm{~mm}$ and retained in $2.36 \mathrm{~mm}$.

\subsection{Coarse Aggregate}

The size from $40 \mathrm{~mm}$ to $4.75 \mathrm{~mm}$ are termed as coarse aggregate[14]. The coarse aggregates retained at $20 \mathrm{~mm}$ is taken for $60 \%$ and the coarse aggregates retained at $10 \mathrm{~mm}$ is taken for $40 \%$.The fine aggregates taken by passing from $4.75 \mathrm{~mm}$ and retained in $2.36 \mathrm{~mm}$. The w/c ratio is taken for M20 grade is $0.5 \%$ and for M40 grade is $0.4 \%$.

\subsection{Testing Of Fine And Coarse Aggregate}

The fine aggregate are arranged in order of $4.75 \mathrm{~mm}$, $2.36 \mathrm{~mm}, 1.18 \mathrm{~mm}, 600 \mu, 425 \mu, 300 \mu, 150 \mu$ and $75 \mu$ and are sieved[13]. The coarse aggregate are arranged of $40 \mathrm{~mm}$, $25 \mathrm{~mm}, 20 \mathrm{~mm}, 16 \mathrm{~mm}, 12.5 \mathrm{~mm}, 10 \mathrm{~mm} 4.75 \mathrm{~mm}$ and pan.

\subsection{Casting Procedure}

The tray is taken, cleaned and dried up. The fine aggregate is measured by weight and dropped into the tray. The coarse aggregate are sieved well measured by weight and dropped into the tray. The PPC cement which is closed and kept are taken carefully without the entry of air[10]. The hypo sludge is also taken by weight. The ratios of water are taken for 0.5 and 0.45 . The materials are well mixed using trowel and are casted.

\subsection{Properties of Hypo Sludge}

This hypo sludge has a maximum content of calcium chloride and very low amount calcium and moderate amount of silica[2]. This types of Lime sludge acts like cement because of silica and magnesium properties which has contain in hypo sludge[3]. This magnesium and silica will also improves the initial setting of the cement mortar. Hypo Sludge properties is Mentioned in the table 1.

Table 1: Properties of Hypo Sludge

\begin{tabular}{|c|c|}
\hline Constituent & Present \\
\hline Moisture & $56.8 \%$ \\
\hline Mgo & $3.3 \%$ \\
\hline Cao & $46.2 \%$ \\
\hline LOI & $27.0 \%$ \\
\hline Acid & $11.1 \%$ \\
\hline $\mathrm{SiO} 2$ & $9.0 \%$ \\
\hline $\mathrm{R} 2 \mathrm{O} 3$ & $3.6 \%$ \\
\hline
\end{tabular}

\section{TEST RESULTS AND DISCUSSIONS}

\subsection{Compression Strength}

The compressive strength concrete by replacing hypo sludge according to range of $10 \%, 20 \%$ and $30 \%$ in the specified design mix was examined. The compression test was determined at 7 days of M20 and M40 by using compression testing machine of $2000 \mathrm{KN}$ capacity.The compressive strength for cube are calculated using Load/Area[6]. The experiment has conducted in the concrete cube in figure 2 and the crack Patten of the concrete cube figure 3 . The experimental values which has determined in the table form which is noted in the table 3 and table 4 , which is plotted as the chart in the figure 4 and figure 5 .
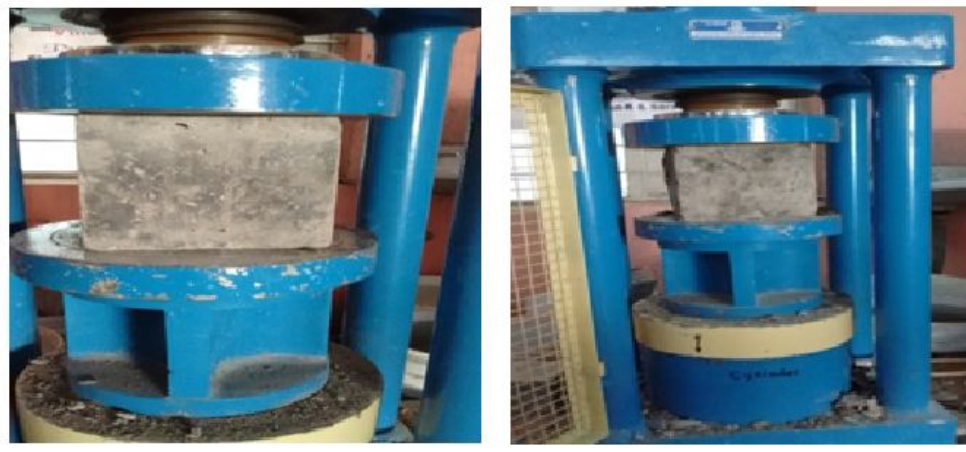

Figure 2: Compression testing procedure

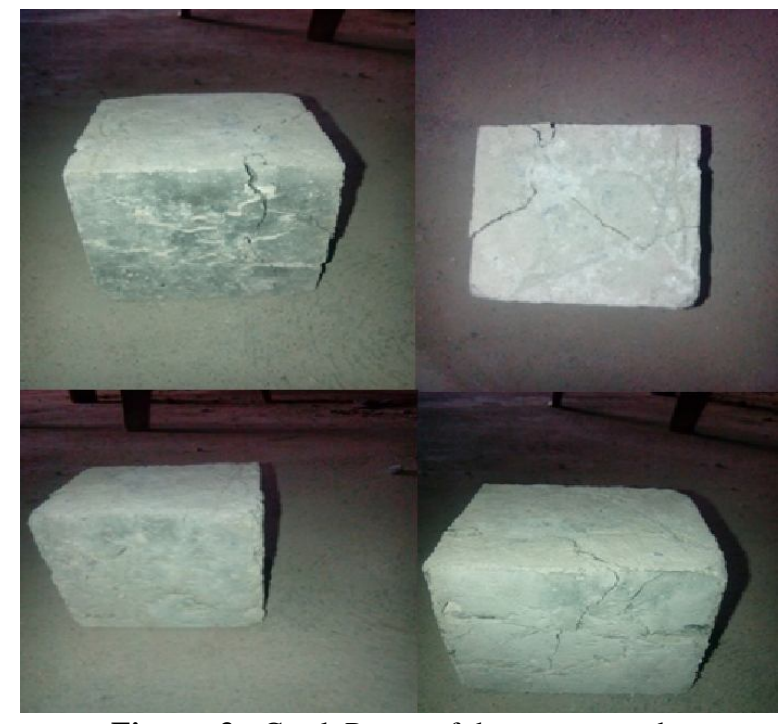

Figure 3 : Crack Patten of the concrete cube

Table 2 : Compressive Strength for 7 and 28 days of M20 Grade

\begin{tabular}{|c|c|c|}
\hline \% REPLACEMENT & $\begin{array}{c}\text { 7 DAYS } \\
\text { kN/m2 }\end{array}$ & $\begin{array}{c}\text { 28 DAYS } \\
\text { kN/m2 }\end{array}$ \\
\hline Normal & 14.22 & 24.88 \\
\hline $10 \%$ & 14.01 & 26.11 \\
\hline $20 \%$ & 13.80 & 27.20 \\
\hline $30 \%$ & 13.33 & 27.00 \\
\hline
\end{tabular}




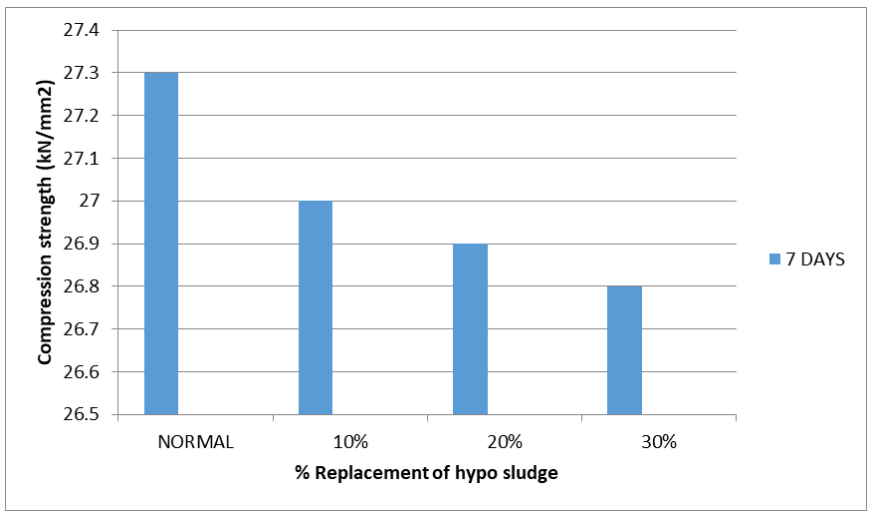

Figure 4: Compressive Strength vs partial replacement of Hypo

\begin{tabular}{|c|c|c|}
\hline \% REPLACEMENT & 7 DAYS N/m2 & 28 DAYS N/m2 \\
\hline Normal & 27.3 & 46.3 \\
\hline $10 \%$ & 27.0 & 48.1 \\
\hline $20 \%$ & 26.9 & 48.6 \\
\hline $30 \%$ & 26.8 & 47.4 \\
\hline
\end{tabular}

Table 3: Compressive Strength for 7 and 28 days for M40 Grade

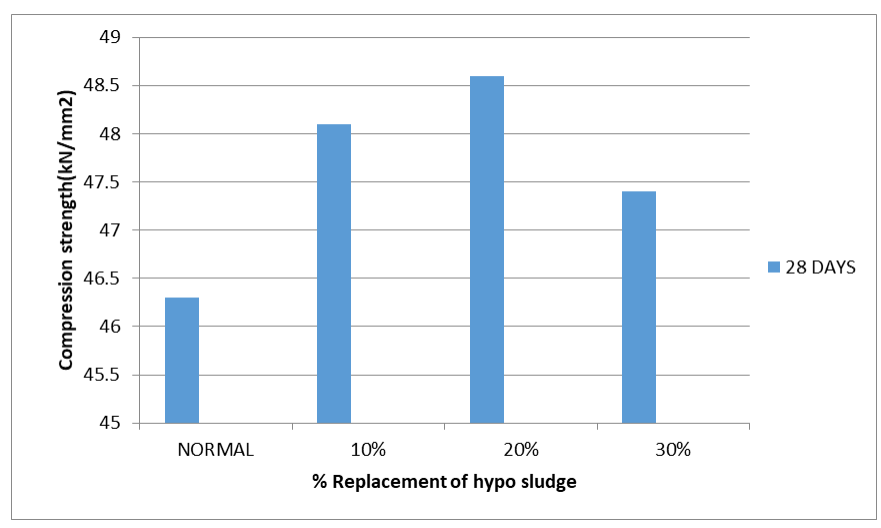

Figure 5 : Compressive Strength vs Partial Replacement of hypo sludge for M40 Grade of 28

\subsection{FLEXURAL STRENGTH}

The concrete beam is casted for $(10 \times 10 \times 50 \mathrm{~cm})$ and kept in water and it is taken be casted and kept in water and it is taken out from the curing tank, cleaned, wiped and kept for half an hour[8]. The deflectometer is placed at center of the span. The load is applied till the specimen fails. The distance between the support and failure point is noted[9, 18]. The experimental investigation on concrete beam which has shown in the figure 6 and the experimental values has taken in the table 4 and table 5, which the result has plotted as the graph in the figure 9 and figure 10 . The failure crack Patten of the concrete beam is shown in the figure 7 and rupture of the concrete beam has shown in the figure 7 .

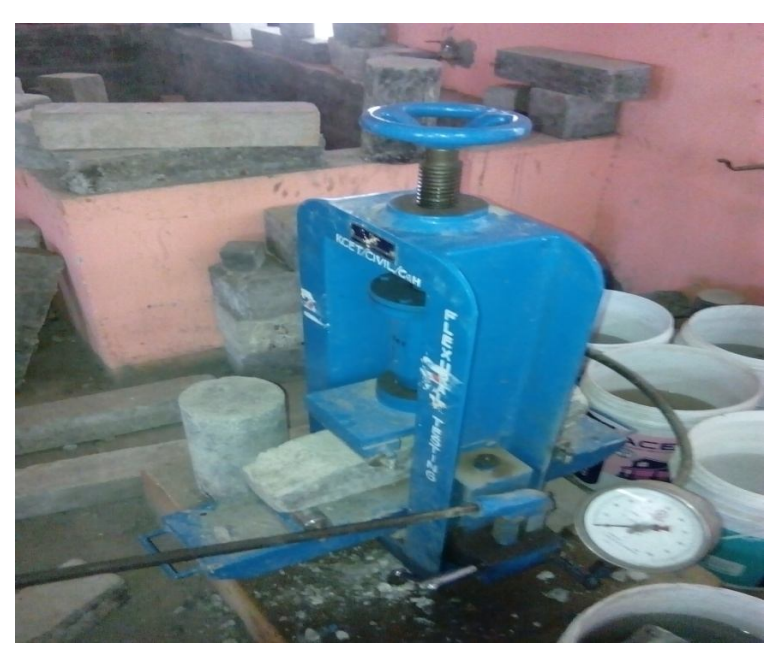

Figure 6: Test under Flexural Testing Machine

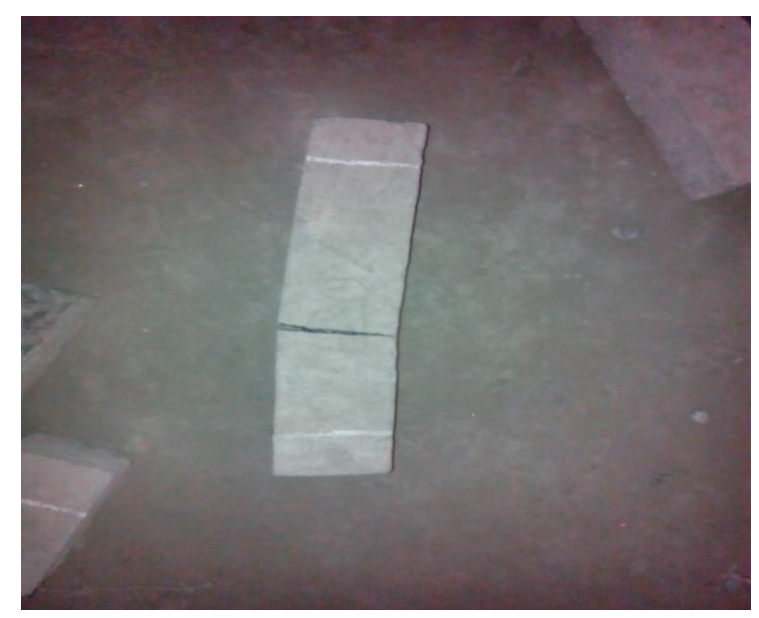

Figure 7: Cracking Pattern of Beam

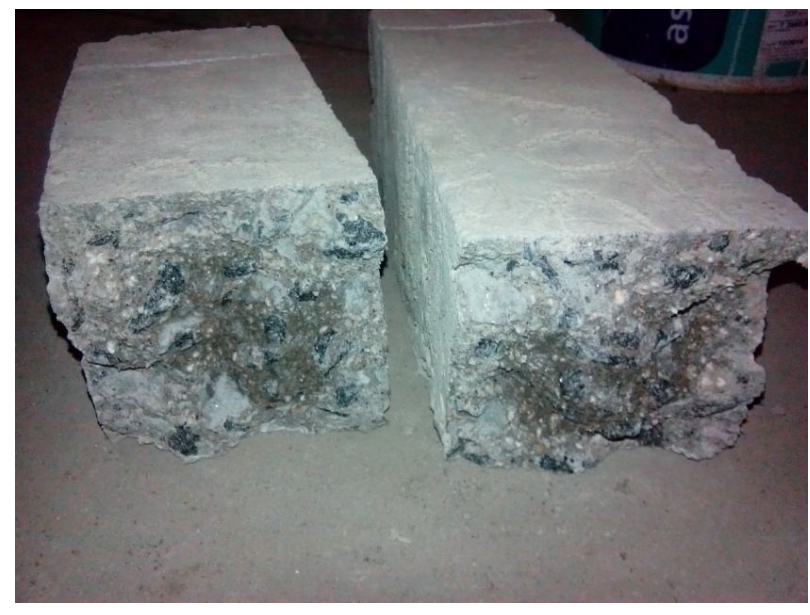

Figure 8: Rupture of Beams

Table 4 : Flexural Strength of 7 and 28 days for M20 grade

\begin{tabular}{|c|c|c|}
\hline REPLACEMENT \% & 7 DAYS & 28 DAYS \\
\hline $0 \%$ & 3.64 & 7.50 \\
\hline $10 \%$ & 6.40 & 12.42 \\
\hline $20 \%$ & 7.52 & 14.20 \\
\hline $30 \%$ & 6.76 & 13.00 \\
\hline
\end{tabular}




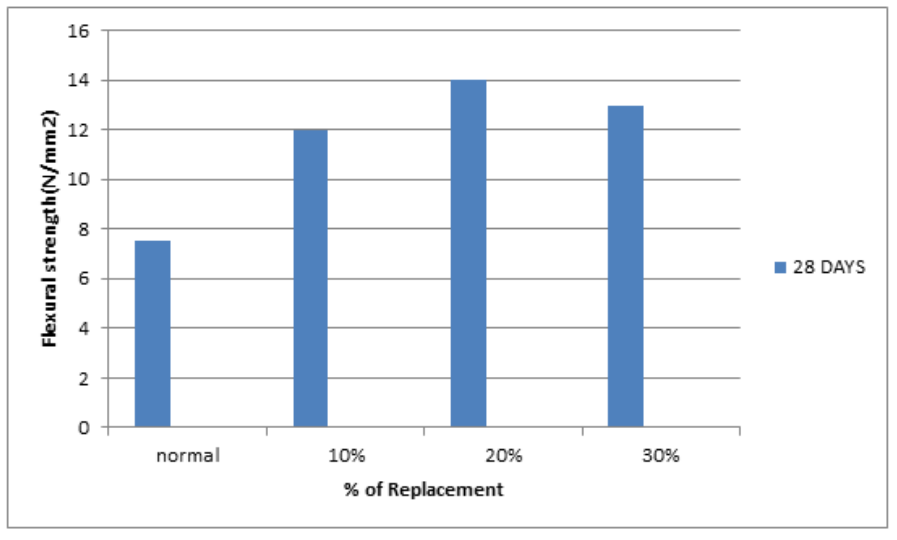

Figure 9 : Flexural Strength vs Partial Replacement of M20 Grade for 28 Days

\begin{tabular}{|c|c|c|}
\hline REPLACEMENT & 7 DAYS & 28 DAYS \\
\hline $0 \%$ & 4.50 & 9.00 \\
\hline $10 \%$ & 6.76 & 13.5 \\
\hline $20 \%$ & 8.24 & 16.2 \\
\hline $30 \%$ & 7.00 & 15.0 \\
\hline
\end{tabular}

Table 5: Flexural strength of 7 and 28 days of M40 grade

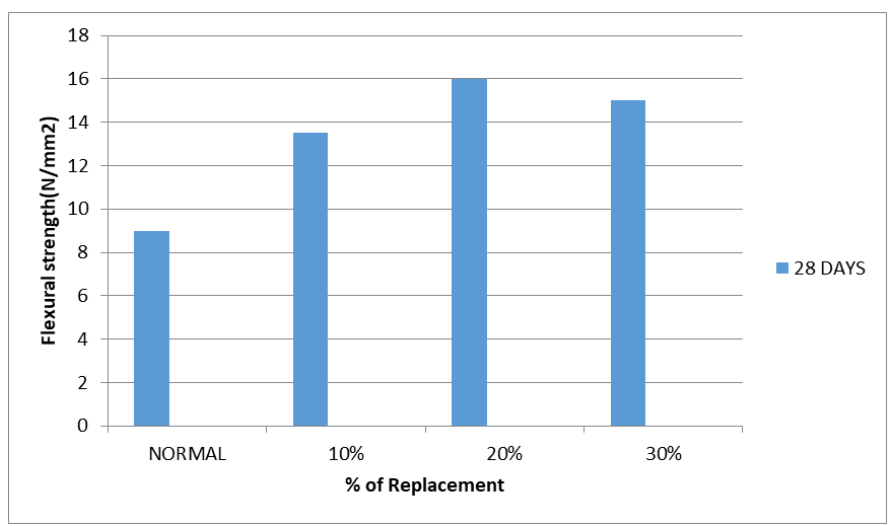

Figure 10 : Flexural Strength vs Partial Replacement of M40 Grade for 28 Days

\subsection{YOUNG'S MODULUS}

The modulus of versatility is significant property to decide the avoidance of the basic component[10,17]. Avoidance of cement in light emissions is basic structure movement.It additionally referenced that the diversion is aftereffect of the flexural strains that create under dead burden and live burden[11]. The modulus of flexibility can be determined by the distinction of estimated stresses and strains on an upper level and lower level. The experiment has conducted to the concrete cylinder in figure 11 and the crack Patten of the concrete cylinder is shown in the figure 12 . The experimental values has tabulated in the table 6 and table 7 , which has plotted as graph which shown in the figure 13 and figure 14 .

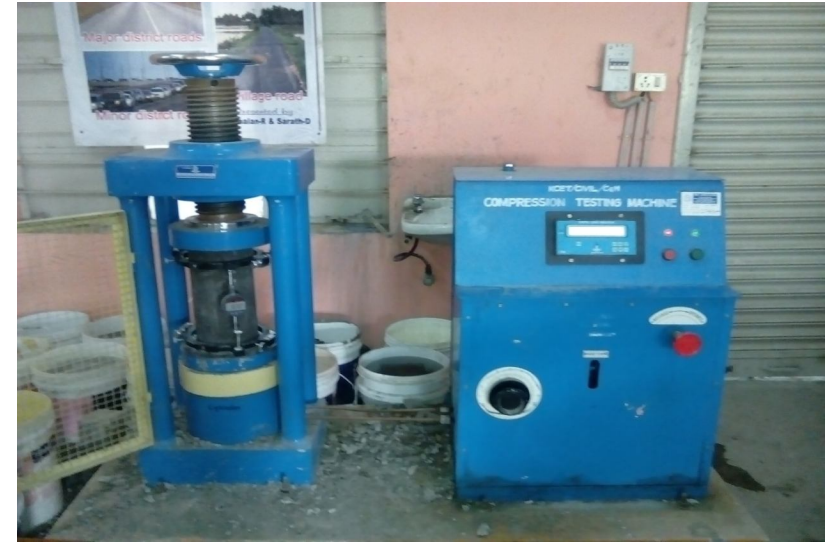

Figure 11 : Young's Modulus of Cylinder

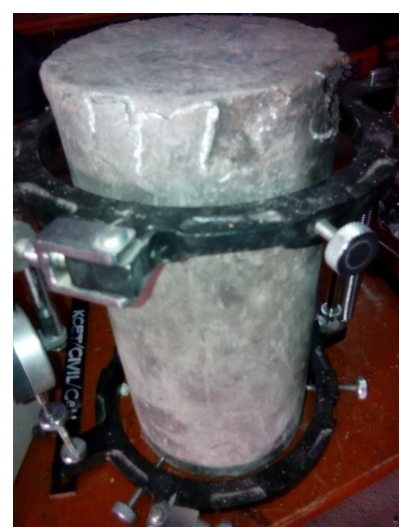

Figure 12: Cracking Pattern of Concrete Cylinder

\begin{tabular}{|c|c|c|}
\hline \multicolumn{3}{|c|}{ AVERAGE ELASTICITY OF MODULUS } \\
\hline $\begin{array}{c}\text { TEST } \\
\text { CONCRETE }\end{array}$ & $\begin{array}{c}\text { ELASTICITY OF } \\
\text { MODULUS }\end{array}$ & $\begin{array}{c}\text { \% CHANGE IN } \\
\text { MODULUS OF } \\
\text { ELASTICITY }\end{array}$ \\
\hline NORMAL (\%) & 23425.65 & 0 \\
\hline $10 \%$ & 25672.52 & $3.54(+)$ \\
\hline $20 \%$ & 24345.21 & $5.19(-)$ \\
\hline
\end{tabular}

Table 6: Average Young's Modulus of M20 Grade

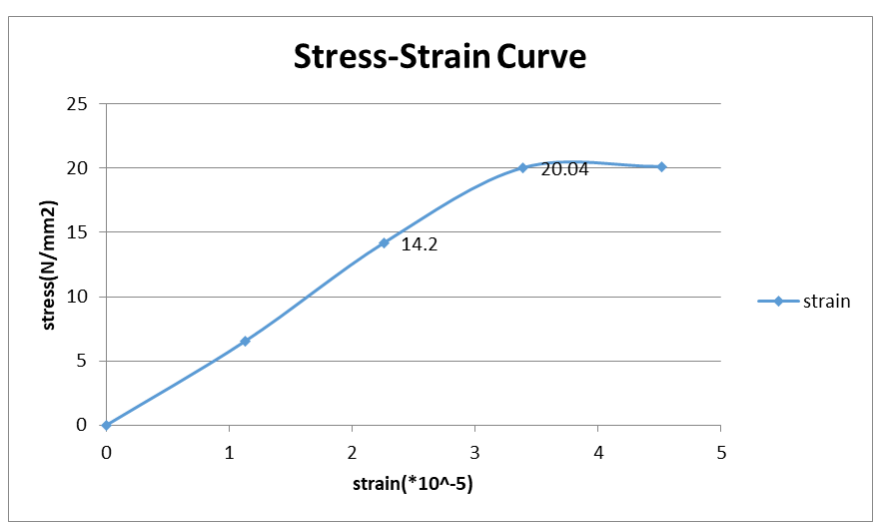

Figure 13: Stress strain value of M20 Grade 
D.S.Vijayan et al., International Journal of Emerging Trends in Engineering Research, 8(9), September 2020, 5490 - 5495

Table 7: The average young's modulus of M40 grade

\begin{tabular}{|c|c|c|}
\hline \multicolumn{3}{|c|}{ AVERAGE ELASTICITY OF MODULUS } \\
\hline $\begin{array}{c}\text { TEST } \\
\text { CONCRETE }\end{array}$ & $\begin{array}{c}\text { ELASTICITY } \\
\text { OF MODULUS }\end{array}$ & $\begin{array}{c}\text { \% CHANGE IN } \\
\text { MODULUS OF } \\
\text { ELASTICITY }\end{array}$ \\
\hline NORMAL $(0 \%)$ & 25785.65 & 0 \\
\hline $10 \%$ & 26734.52 & $3.54(+)$ \\
\hline $20 \%$ & 25345.21 & $5.19(-)$ \\
\hline
\end{tabular}

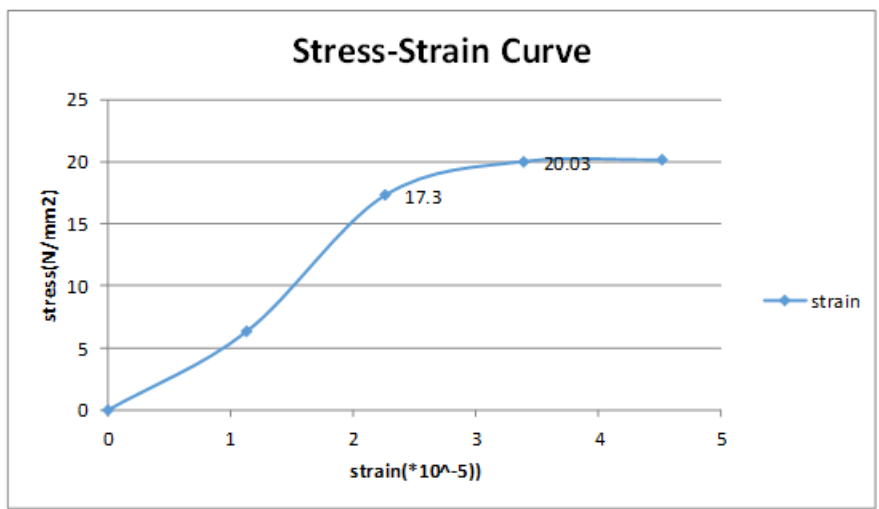

Figure 14 : Stress strain value of M40 Grade

\section{CONCLUSION}

The replacement of hypo sludge instead of cement results in increase in $\%$ of concrete upto $20 \%$ for cube and beam and upto $10 \%$ for cylinder. The compressive strength of M20 grade and M40 grade are 24.88 and $46.3 \mathrm{~N} / \mathrm{m} 2$. The compressive strength of normal compared with hypo sludge concrete for M20 grade are $5.82 \%, 9.32 \%$ and $8.52 \%$ for M40 grade are $6.84 \%, 8.75 \%$ and $4.18 \%$. The M20 grade is higher than M40 grade in compressive strength. The flexural strength of normal M20 and M40 grade are 7.50 and 9.00 $\mathrm{N} / \mathrm{m} 2$. The flexural strength of normal compared with hypo sludge concrete for M20 grade are 65\%, 89.33\% and 73.33\% for M40 grade are 50\%, $80 \%$ and $66.6 \%$. The M20 grade is higher than M40 grade in flexural strength. The young's modulus (E) for normal M20 and M40 grade are $(0.257 * 105)$ and $\left(0.23425^{*} 105\right) \mathrm{N} / \mathrm{mm} 2$. The young's modulus (E) of normal compared with hypo sludge M20 grade are 3.67 and $1.70 \%$ The young's modulus (E) of normal compared with hypo sludge M40 grade are 9.59 and 3.92\%. The M40 grade is higher than M20 grade in young's modulus. For cube and beam it achieves its strength till $20 \%$ for cylinder it achieves its strength till $10 \%$.

\section{REFERENCES}

1. S.Aravindan, et al, "Characteristic Study of Concrete by Replacing Glass Cullet and Ceramic Tiles over Conventional Aggregates", INTERNATIONAL JOURNAL OF SCIENTIFIC \& TECHNOLOGY RESEARCH, VOLUME 8, ISSUE 10, 2019, Pno -1802 -1805 .
2. Vijayan, D.S. Parthiban, D." Effect of Solid waste based stabilizing material for strengthening of Expansive soil- A review, Environmental Technology and Innovation Volume 20, November 2020, Article number 101108, DOI: 10.1016/j.eti.2020.101108

3. Balamurugan. R (2010), "A Study of Future Trend for Sustainable Development by Incorporation of SCM's" International Journal Of Scientific Research, Vol.2,pp:110-115.

4. Ritesh A. Patel, (2009) Flexural Strength of Beams by Partial Replacement of Cement with Fly Ash and Hypo Sludge in Concrete, International Journal of Engineering Science and Innovative Technology (IJESIT) Vol.2, pp-173-179.

5. Vaidevi, C. et.al"Strength of concrete hollow block with used plastic bottles", International Journal of Scientific and Technology ResearchVolume 9, Issue 2, February 2020, Pages 6456-6457

6. Vaidevi, C. et.al "Experimental study on properties of self-compacting concrete with marble waste", international Journal of Applied Engineering Research Volume 10, Issue 33 Special Issue, 2015, Pages 24183-24186

7. Jayeshkumar Pitroda, (2011) Director Central Road Research Institute New Delhi. Utilization of fly ash in road construction ,pp: 60-63.

8. IS 10262-2009, Concrete mix proportioning guidelines (First revision), Bureau of Indian standards.

9. IS: 456- 2000 (Fourth Revision), Plain and Reinforced Concrete, Indian Standard code of practice, Bureau of Indian Standards.

10. IS383- 1970, Specification for coarse and fine aggregates from natural sources for concrete (Second revision), Bureau of Indian standards.

11. Thi, N.N.Email Author, Hoang, M.D." Sustainable solution for industrial waste at the coal mining site", International Journal of Emerging Trends in Engineering Research, Volume 8, Issue 7, July 2020, Pages 3452-3456.

12. Siddhartha Talsania, (2015) Use of Non- Conventional Materials for the Construction of Low-volume roads,pp:27-38.

13. Mohammad Ismail, (2005) Hypo Sludge Management: Opportunities For Developing Low Cost Concrete With Glass Fibres" International Journal Global Research

14. Umrigar F.S, (2012) "Harmonising Environment and Ecological Sustainability by Utilization of Fly Ash in Rigid Pavement" International Journal Global Research Analysis, (GRA), Vol:2 pp:97-99.

15. D. Parthiban et al, "Study on Stress-Strain effect of reinforced Metakaolin based GPC under compression", Materials Today: Proceedings, https://doi.org/10.1016/j.matpr.2019.10.162

16. D. S. Vijayan et al., "Evaluation of ferrock: A greener substitute to cement", Materials Today: Proceedings, https://doi.org/10.1016/j.matpr.2019.10.147 
D.S.Vijayan et al., International Journal of Emerging Trends in Engineering Research, 8(9), September 2020, 5490 - 5495

17. C. Vaidevi et .al, "Mechanical and durability properties of self-compacting concrete with marble fine aggregate", Volume 22, Part 3, 2020, Pages 829-835, https://doi.org/10.1016/j.matpr.2019.11.019

18. B. Saravanan et al, Status review on experimental investigation on replacement of red-mud in cementitious concrete, Materials Today: Proceedings, https://doi.org/10.1016/j.matpr.2020.05.500 